\title{
Essays
}

\section{Contract Bankruptcy:}

\section{A Reply to Alan Schwartz}

\author{
Lynn M. LoPucki ${ }^{\dagger}$
}

Since the publication of Professor Robert Rasmussen's landmark article in 1992, ${ }^{1}$ the central focus of bankruptcy scholarship has been to discover a practical method of contracting for bankruptcy procedure." The task is difficult because a debtor may have hundreds or even thousands of creditors whose interests will be interdependent at the time of insolvency. The contract by which they select a bankruptcy procedure optimal for the particular firm would have to be a contract among all of them, and it would have to be capable of changing over the years as the firm evolved. ${ }^{3}$

The theory of business bankruptcy that dominated the scholarship until recently-Professors Douglas Baird and Thomas Jackson's “creditor's bargain" theory - was based on the assumption that actually making such a contract was impossible. Instead, Baird and Jackson sought to discover and

$\doteqdot$ Security Pacific Bank Professor of Law, UCLA Law School. I thank Bob Rasmussen. Susan Block-Lieb, Hulya Eraslan, Frances Foster, Ted Janger, Ken Klee. Ronald Mann. Stewart Schwab, Steve Schwarcz, Elizabeth Warren, and Walter Weyrauch for comments on earlier drafts.

1. See Robert K. Rasmussen, Debtor's Choice: A Menu Approach to Corporate Bankruptcy. 71 TEX. L. REV. 51 (1992) (proposing contracting for bankruptcy procedure through provisions in corporate charters).

2. Reviews of the literature appear in Steven L. Schwarcz, Rethinking Freedom of Contract: A Bankruptcy Paradigm, 77 TEX. L. Rev. 515, 529-34 (1999), and Susan Block-Lieb. The Limits of Neo-Libertarian Contract Theory: Comparing Contractual and Statutory Approaches to Business Bankruptcy 9-28 (1999) (unpublished manuscript, on file with The Yale Law Journal).

3. See, e.g., Alan Schwartz, A Contract Theon' Approach to Business Bankruptcy, 107 YALE L.J. 1807, 1821-22 (1998) ("The contract theory problem is serious, however, because the optimality of a bankruptcy system is state-dependent: Under some values of the ex post economic parameters, it would be efficient to liquidate the firm. while under other values, reorganization would be best."). 
impose on all parties to bankruptcy cases the contract they would have chosen had contracting been possible. ${ }^{4}$

In the early 1990s, several bankruptcy scholars challenged the assumption that such contracting was impossible. ${ }^{5}$ One, Rasmussen, also proposed a method for adjusting the contract over time. The state would offer a "menu" of alternative bankruptcy regimes, and business debtors would select among them by inserting provisions in their corporate charters. ${ }^{6}$ Changes in the election would be made by charter amendment. Prospective lenders could discover the debtor's chosen bankruptcy regime from the public record and refuse to extend credit if they did not approve. ${ }^{8}$ Rasmussen's proposal was of doubtful practicality, ${ }^{9}$ in part because all parties had to update their information and recontract with changing conditions. But the proposal demonstrated that regimes of actual contracting were possible, and it inspired other scholars to attempt to improve upon it. ${ }^{10}$

The most ambitious of those attempts to date is the one by Professor Alan Schwartz that was published in The Yale Law Journal in 1998. Schwartz proposed an elegant scheme in which the debtor would need to negotiate changes only with the most recent creditor and in which that creditor could rely upon information voluntarily disclosed by the debtor."

4. See, e.g., Thomas H. Jackson, Avoiding Powers in Bankruptcy, 36 STAN. L. Riv. 725.728 (1984) ("Bankruptcy's rules therefore can be seen as an attempt to implement the type of collective and compulsory system that rational creditors would privately agree to if they could bargain together before the fact.").

5. See, e.g., Barry E. Adler, Financial and Political Theories of American Corporate Bankruptcy, 45 STAN. L. REV. 311 (1993) (proposing contracting through the design of securities); Michael Bradley \& Michael Rosenzweig, The Untenable Case for Chapter 11, 101 YALE L.J. 1043 (1992) (same).

6. See Rasmussen, supra note 1 , at 54-55, 112.

7. See id.

8. Rasmussen later described his proposal as follows:

Firms would be allowed to change the bankruptcy provisions of their charters (or include a new provision if one does not already exist) subject to two constraints. The first is that there be a lag between the time a firm announces that it intends to change its bankruptcy selection and when that change is effective. This lag would give the creditors the opportunity to examine the proposed change. If they ascertained that the change was an attempt to enrich the managers at their expense, they could . . . initiate an insolvency proceeding prior to the change taking effect.

Robert K. Rasmussen, Free Contracting in Bankruptcy at Home and Abroad, in THE FALL AND RISE OF FREEDOM OF CONTRACT 311,319 (F.H. Buckley ed., 1999).

9. See Lynn M. LoPucki, Cooperation in International Bankruptcy: A Post-Universalist Approach, 84 CORNELL L. REV. 696, 738-42 (1999) (criticizing Rasmussen's proposal on the grounds that the cost of contracting would be excessive and that involuntary creditors would not have the opportunity to contract); Schwartz, supra note 3, at 1811 (noting that Rasmussen's solution "may founder over the problem that because the optimality of a bankruptcy system is state-dependent, it also can be time-dependent").

10. See Block-Lieb, supra note 2, at 9-28 (describing the contractual bankruptcy literature and critiquing the various proposals).

11. See Schwartz, supra note 3. 
Had it worked, Schwartz's method would have been in some respects more efficient than Rasmussen's. ${ }^{12}$ But what was most intriguing was Schwartz's claim to have proven, with the precision of an elaborate economic model, that permitting parties to contract for the bankruptcy systems they preferred would be superior to the current system of "statesupplied bankruptcy." ${ }^{13}$ That is, Schwartz asserted that his model proved the superiority of contract bankruptcy over the current system in a manner applicable to the real world, ${ }^{14}$ and he advocated a change in current law based upon it. ${ }^{15}$

Though scholars have questioned some of the assumptions underlying Schwartz's model as unrealistic, ${ }^{16}$ to date his proof has been accepted as correct on its assumptions. ${ }^{17}$ Rasmussen himself hailed it as "a major contribution to the bankruptcy literature" that "provides the first formal confirmation of the intuition that firms, acting prior to the onset of financial distress, are better able to select the appropriate bankruptcy procedure than is a mandatory rule ...." 18

Schwartz's proof is defective. The model employs materially inconsistent assumptions and the proof reaches its goal only through miscalculations from those assumptions. To understand the nature and significance of these errors, the reader must first understand the operation of the model. To accomplish that, this Essay proceeds by restating the purpose and essential assumptions of Schwartz's model and tracing his proof in nontechnical language. To facilitate comparison with the technical language of Schwartz's essay, it includes extensive footnotes to the essay, uses verbal expressions that correspond to the symbolic expressions of

12. In particular, onily the debtor and one creditor would have had to analyze the circumstances and negotiate updates to the bankruptcy contract. See id. at 1834 .

13. Schwartz makes the claim in two sentences, whose placement in the cssay indicates that they are asserted to flow from the model rather than from arguments made in other parts of the essay. The first is that " $[t]$ he legal prohibition on contracting for bankruptcy systems is inefficient because the ban requires parties always to use 'renegotiation contracts' even when other contracts would generate higher expected values for creditors." Id. at 1831. The second, which follows the first by only a few sentences, is that "[f]irms today cannot finance projects that they would be able to finance if the ban were repealed." Id. at 1832 .

14. See id; id. at 1838 ("In sum, if the ban on contracting for bankrupicy systems were repealed ... the current U.S. system would make a better contribution to the maximization of social wealth."); id. at 1850 ("Requiring parties to use a single, state-supplied bankruptcy system does not maximize the value of bankruptcy estates ....").

15. See id. ("[T]he state should permit parties to contract for the bankrupicy system that they prefer."). Later he describes "[t]his Essay's central claim" as "captured in a variation on a trendy slogan: Privatize bankruptcy." Id. at 1851 .

16. See, e.g., Rasmussen, supra note 8, at 314-15 (objecting to Schwartz's assumption that the only choice for bankruptcy contracting is between liquidation and reorganization); BlockLieb, supra note 2, at 60 (arguing that Schwartz "too quickly presumes the existence of an appropriate signal" for partially renegotiation-proof contracts).

17. See, e.g., Schwarcz, supra note 2, at 600 ("Professor Alan Schwartz has shown that [bankruptcy] procedure contracts can benefit both debtors and creditors.").

18. Rasmussen, supra note 8 , at 319. 
Schwartz's model, and indicates the symbolic expression in brackets when such a verbal expression is used.

The three-part task Schwartz sets for himself is to demonstrate that a set of bankruptcy contracts exists that would induce optimal bankruptcy choices even though " [a] firm may have numerous creditors; these creditors may lend at different times; and they may have different preferences about bankruptcy systems." 19 He constructs his model in three stages that correspond to these three parts. At its first stage, the model proves that "a set of contracts that will induce optimal bankruptcy choices exists" when a debtor has numerous creditors. ${ }^{20}$ Expanded to the second stage, the model purports to prove that "[a] set of contracts exists that will achieve the results described above even though creditors lend at different times." 21 Further expanded to its third stage, the model purports to prove that inconsistent preferences among creditors would not prevent the parties from reaching agreement.

Part I of this Essay describes the first stage of Schwartz's model and his proof that contracting would occur on the assumptions at that stage. Part II describes the extension of the model to its second stage and demonstrates that Schwartz has ignored in this stage assumptions that were crucial to the first stage. Part III describes the further extension of the model to its third stage. It demonstrates that Schwartz's contracting solution to the conflict between junior and senior creditors fails because it misapprehends the source of conflict between them, and that his contracting solution to the conflict between trade and other creditors-majority rule-fails because it is inconsistent with his second stage solution-the last contract governs. Part IV examines the sparse empirical evidence to conclude that actual bankruptcy contracting is proceeding in directions less benign than those predicted by Schwartz and other theorists. Part V summarizes the arguments presented and conclusions reached in the preceding parts.

\section{STAGE ONE: CONTRACTING WHEN ALl CREDITORS LEND AT THE SAME TIME}

Schwartz's model assumes only a single subject for bankruptcy contracting: whether the case should be a reorganization or liquidation. ${ }^{22}$

\footnotetext{
19. Schwartz, supra note 3 , at 1822.

20. Id.

21. Id. at 1833 .

22. See id. at 1823 . Schwartz does not explain why proof that a bankruptcy contract was superior to the current system in one respect, the choice between reorganization and liquidation. would prove that bankruptcy contracts were superior to the current system in all respects. $C f$. Rasmussen, supra note 8, at 315 ("Schwartz does not propose, as his model suggests. that Congress amend the Bankruptcy Code so as to allow firms to enter into contracts regulating whether the firm should file for liquidation or reorganization."). Schwartz's unstated premise
} 
For each firm, reorganization or liquidation might be best, depending on the state of facts existing at the time of bankruptcy. ${ }^{23}$ The obvious solution to the contracting problem presented-a contract providing that the firm will choose liquidation when liquidation is best $\left[\theta_{L}\right]$ and reorganization when reorganization is best $\left[\theta_{R}\right]$-is blocked by an assumption that the contract would be too expensive to write. ${ }^{24}$

The model assumes that the firm makes the choice between reorganization and liquidation at the time of bankrupicy, ${ }^{25}$ knows at that time which is best, ${ }^{26}$ knows the amount of the loss it will inflict on the creditors if it chooses reorganization when liquidation is best, ${ }^{27}$ but cannot be trusted to choose the best because its incentives are biased in favor of reorganization. ${ }^{28}$ The bias results from the firm' $\mathrm{s}^{29}$ assumed ability to obtain "private benefits" ${ }^{30}$ in reorganization in excess of those that would be available in liquidation $\left[b_{R}-b_{L}\right]$. Though the firm knows the amount of

appears to be that a bankruptcy contract superior in any particular respect could track the current system in every other respect. Because the contract was superior in one respect and inferior in none, it would have to be superior as a whole.

23. Schwartz designates the state of the world in which reorganization is best as $\theta_{2}$ and the state in which liquidation is best as $\theta_{L}$. See Schwartz, supra note 3, at 1825.

24. As Schwartz puts it, "[T]he ex post circumstances and their relation to what an optimal bankruptcy choice would be are too costly to describe in a contract. Thus contracts of the form 'Choose R[eorganization] if certain facts obtain but otherwise choose L[iquidation]' are excluded." Id. at 1823.

25. See id.

26. See id. ("Thus parties know after insolvency which of the two bankruptcy systems would maximize monetary returns.").

27. See id. at $1828 \mathrm{n} .59$ ("[T]he firm can predict the private benefits that it later may realize in bankruptcy and its expected monetary return. As a consequence, the firm can calculate the optimal bribe $s^{*}$ to include in the contract."). The firm could make such a calculation only by knowing $Y_{L L}$ (the firm's monetary return from choosing liquidation) and $Y_{L}$ (the firm's monetary return from inefficiently choosing reorganization) because $s^{\circ}$ depends upon them. See id. al 1828.

28. See id. at 1825 ("It is assumed that the firm derives greater private benefits from system $R$ whichever state of the world obtains ex post-i.e., the firm will always choose system $R$ unless it is constrained by ex ante contract or by ex post renegotiation.").

29. In the model to which this reply is directed, the firm, not the managers or shareholders, reaps the private benefits. See id. at 1824 ("The firm makes an optimal bankruptcy choice when it picks the system that maximizes the sum of monetary retums and privale benefits."). This assumption has a tendency to confuse readers because (1) the real-world comelates of private benefits are consumed outside the firm by managers or shareholders and (2) most of the private benefits are, by their nature, taken from the firm. Examples include " the excess consumption of leisure while employed, and the opportunity to continue to be paid a salary." Id. Schwartz apparently makes this counterintuitive assumption as a means of excluding the shareholdermanager conflict from the scope of his essay. See id. at $1825-26$ \& n.56.

This exclusion conceals a practical problem with any scheme that bribes a firm to file for liquidation. To have the desired effect, the bribe must not only be in the optimal amount: it must also be divided optimally among what may be numerous managers and shareholders. This presents an additional, formidable contracting problem that must be solved before one can conclude that bankruptcy contracting is feasible. I am indebted to Ted Janger for this insight.

30. Schwartz states that " [t]hese benefits are the pleasure or status derived from running the firm, the excess consumption of leisure while employed. and the opportunity to continue to be paid a salary." Id. at 1824 . 
these private benefits, ${ }^{31}$ the model assumes that "lending agreements... cannot ban or regulate private benefits by contract" because they are "unverifiable." ${ }^{32}$ By that, Schwartz means that "the parties cannot establish in court the monetary value of these benefits, nor can they show that the firm is consuming excessively." 33

Schwartz's solution to the contracting problem thus presented is a contract in which the parties agree ex ante that whether the firm chooses reorganization or liquidation, the creditors will permit the firm to keep, as a "bribe," a percentage $[s]$ of the firm's insolvency monetary return $[y]{ }^{34} \mathrm{He}$ proves the optimal percentage $\left[s^{*}\right]$ to be the ratio that the private benefit to the firm of choosing an ill-advised reorganization $\left[b_{L R}-b_{L L}\right]$ bears to the increased monetary return the firm would enjoy from correctly choosing liquidation when it was efficient $\left[y_{L L}-y_{L R}\right] .{ }^{35}$ Although he assumes that percentage is unverifiable, he also assumes that the firm has all the information necessary to calculate it at the time the firm borrows. ${ }^{36}$ Finally, he assumes that the creditors may not have the knowledge necessary to calculate the optimal bribe percentage $\left[s^{*}\right] .^{37}$

On these assumptions, Schwartz concludes that the parties can agree on the optimal bribe percentage $\left[s^{*}\right]$ because the creditors can count on the firm to disclose that percentage accurately at the time of contracting. ${ }^{38}$ Schwartz assumes this accurate disclosure, ${ }^{39}$ but does not explain why it occurs. The reason is that in Schwartz's model, the firm captures the entire value of the

31. See id. at $1828 \mathrm{n} .59$ (" [T]he firm can predict the private benefits that it later may realise in bankruptcy ....").

32. Id. at 1824 .

33. Id.

34. See id. at $1827 \&$ n. 58 .

35. See id. at 1827-28. Schwartz does not explain the purpose of expressing the bribe as a percentage rather than as an amount. Apparently he has assumed that the benefit and the bankruptcy value of the firm may change, but that the relationship between them will not.

36. See id. at 1828 n.59. The argument I present here is an attack on the proof. not on Schwartz's assumptions. Nevertheless, the assumption that the firm knows all of the information necessary to fix the percentage of the bribe seems unrealistic. Firms borrowing money rarely concern themselves with the difference in the amounts of the private benefits they could obtain by later taking the corporation through an ill-advised reorganization rather than an optimal liquidation $\left[b_{L, R}-b_{L L}\right]$. Nor do they ordinarily have any reason to be familiar with bankruptcy procedure, let alone to know the likely amount of the difference in the bankruptcy returns from an ill-advised reorganization rather than an optimal liquidation $\left[y_{L L}-y_{L R}\right]$. If it is Schwartz's assumption that every firm borrowing money would retain bankruptcy experts to conduct the analysis necessary to determine these amounts, the costs would be enormous and the corrupting influence on managers probably even more serious.

37. See id. ("[T]he firm can predict the private benefits that it later may realize in bankruptcy ... . The creditors may not be able to observe the firm's private benefits ....").

38. See id. ("The firm will offer creditors a contract with a bribe of $s^{*}$ when this contract would maximize the creditors' expected insolvency-state return.").

39. The firm is the only one assumed to have knowledge sufficient to calculate the optimal bribe. See id. Yet the parties manage to contract for the optimal bribe. See id. This could occur only if the firm disclosed its knowledge. 
firm and so wants a contract that will maximize that value..$^{+0}$ Firm-value maximization will occur only if the firm has the incentive at the time of bankruptcy to file the optimal type of bankruptcy.

Schwartz's formula fixes the bribe so that it will be equal to the marginal private benefit from choosing ill-advised reorganization $\left[b_{L R}-b_{L L}\right]$ under all conditions. The effect is to align the interests of the firm with those of the creditors. To state it another way, the amount of the bribe creates a good incentive to file liquidations that precisely equals and therefore offsets the bad incentive the private benefits create to file reorganizations. The effect is that the firm maximizes its share in the event of bankruptcy-the bribe-by maximizing the base upon which it is calculated-the monetary return $[y]$. The firm will do that by choosing the optimal form of bankruptcy. ${ }^{41}$

\section{STAGE TWo: CONTRACTING When CREditors LEND AT DIFFERENT TIMES}

Recognizing that a model that assumed all creditors contracted with the firm at the same time would be of "only theoretical interest," 42 Schwartz extends his model to allow creditors to contract with the firm at different times. ${ }^{43}$ At this second stage, the model contemplates two creditors who contract with the firm sequentially at times $t^{\circ}$ and $t^{\prime}$, and assumes that the "optimal bribe may vary over time." 4

Schwartz's solution to this contracting problem is that (1) the firm and the first creditor will fix the bribe percentage at its optimal value $\left[s^{*}\right]$ at their time of contracting, ${ }^{45}$ and (2) to account for later changes in the percentage of the optimal bribe $\left[s^{*}\right]$, the contract will provide two " 'conversion terms'

40. The firm captures the entire value of the firm because the firm kecps the bribe and the creditor loans the firm the full value of the firm less the bribe. To illustrate, when the bribe is fixed at 0.33 , Schwartz states the maximum expected retum available for creditors in his example to be:

$$
E(R)=.8 \times \$ 260+[0.67 \times .2 \times(.3 \times \$ 180+.7 \times \$ 120)]=\$ 226.49 .
$$

Id. at 1829 n.61. Under these assumptions, the value of the bribe would be:

$$
[0.33 \times .2 \times(.3 \times \$ 180+.7 \times \$ 120)]=\$ 9.11
$$

The total of the creditors' expected retum and the bribe is $\$ 226.49+\$ 9.11=\$ 235.60$, see id., the same value the firm would have if "the firm always voluntarily chose the optimal bankruptcy procedure without being bribed," id. at 1829.

41. See id at 1830 .

42. Id at 1833 .

43. See id.

44. Id. at 1834 .

45. See id. 
that will update the creditor's contract as later creditors arrive." 46 Schwartz's solution is incorrect because inclusion of these conversion terms eliminates the firm's incentive to fix the bribe percentage optimally in the contract with the first creditor.

The first conversion term provides that "if the bribe that the time $t$ ' parameters imply differs from the bribe that the $t^{o}$ parameters implied, the bribe in the first contract will convert to the bribe in the second contract." 47 One purpose of this term is to make sure that all contracts provide for the same bribe at the time of bankruptcy. ${ }^{48}$ Though Schwartz never addresses the point directly, he clearly intends that the terms of the initial creditor's loan other than the percentage of the bribe be unaffected by conversion, even though the creditor initially fixed them dependent on the amount of the bribe, which conversion has changed. ${ }^{49}$

In the model's second stage, Schwartz incorrectly assumes that the firm would present the initial creditor with a contract that fixed the bribe percentage optimally at the time. ${ }^{50}$ The firm did present the creditors with such a contract in the model's first stage, but only because the assumptions of the first stage gave the firm incentives to do so. ${ }^{51}$

The firm's incentives are materially different in the initial contract at the model's second stage. The bankruptcy contract with the initial creditor

46. Id.

47. Id.

48. See id. ("The conversion term also ensures that the firm"s contracts will be consistent: As of bankruptcy, all contracts will have the same bribe.").

49. Had Schwartz intended that conversion of the bribe result in adjustment of the other terms of the initial creditor's contract, Schwartz would have had to consider how the adjustment would be made. Were it necessary for the initial creditor and the firm to agree on terms appropriate to the new bribe, Schwartz's solution would have lost the advantage it had over Rasmussen's. See supra note 9 and accompanying text. If the adjustment were to be made in accordance with a formula contained in the contract with the initial creditor. Schwartz would have had to describe the formula and demonstrate its practicality. In either case, some mechanism would be needed to alert the initial creditor that the bribe had been converted. Two passages in Schwartz's essay evidence his intent that the other terms of the initial creditor's contract should not adjust for a later change in the bribe. The first is Schwartz's acknowledgment that the firm could sometumes gain by declining to fix the bribe optimally. See Schwartz, supra note 3, at 1835 . If the terms of the original contract adjusted, the firm would always do better by fixing the bribe optimally and allowing the adjustment to occur. In the second. Schwartz explains why the initial creditor would sign a contract that fixed the bribe based on conditions at $t^{\circ}$ even though the creditor was aware the conditions might change and the bribe with them. See id. at 1834. Schwartz's sophisticated analysis that "[t]he first creditor would agree to a contract with this feature because the optimal bribe for it will not vary in expectation, and also because the initial creditor always wants the firm to make an optimal bankruptcy choice" and that "the best estimate of the value that $s^{*}$ will take at $t^{2}$, when bankruptcy-relevant variables are finally realized, is the value for $s^{*}$ when estimated as of $t^{o}$," id., would not have been necessary if the initial terms of lending adjusted to the new bribe. The initial creditor would have been fully protected by the adjustment.

50. The assumption is implicit. Schwartz simply begins the section by assuming that such a contract is available for the first creditor to sign. See Schwartz, supra note 3, at 1834 ("The initial creditor has an incentive to sign this contract .....").

51. See supra notes $38-41$ and accompanying text. 
would not be the firm's last. ${ }^{52}$ Realizing that, the firm would also realize that the bribe percentage fixed in the contract with the initial creditor would never determine the bribe payable at bankruptcy. The bribe percentage fixed in the initial contract would always convert to the bribe percentage fixed in the second. Thus, the constraint that caused the firm to disclose accurately in the model's first stage-fear that a suboptimal recovery would result from the fixing of a suboptimal bribe-is absent from the process of contracting with the initial creditor in the second stage.

Freed of that constraint, the firm's incentives in contracting with the initial creditor would be to minimize the bribe percentage $[s]$ in order to maximize the amount that the creditors would expect to receive in the event of insolvency and thereby borrow on the most favorable terms. Because the firm has the information necessary to fix the optimal bribe, ${ }^{53}$ though the creditors may not, ${ }^{54}$ the firm could at least sometimes deceive the initial creditor as to the optimal percentage. If the firm succeeded in its deception, the firm would be able to borrow on more favorable terms. ${ }^{\text {ss }}$ Having borrowed on overly favorable terms that would not change, ${ }^{56}$ the firm could then consolidate its gains by entering into a contract with the second creditor that fixed the bribe at the optimal percentage. ${ }^{57}$

This malfunctioning of Schwartz's proposed bankruptcy contract does not merely redistribute wealth. The initial creditor would realize that the first conversion term gave the firm the incentive to misreport the optimal percentage of the bribe to the initial creditor and the ability to profit at the initial creditor's expense by so doing. For that reason, the initial creditor would refuse to contract. Faced with this failure of contracting, the firm would wish to make an honest disclosure, but the possibility of such disclosure is inconsistent with Schwartz's assumption that the private benefits are "unverifiable." $\$ 8$ On Schwartz's assumptions, the correct

52. See Schwartz, supra note 3, at 1833 (“[L]et a firm have two creditors, with the first arriving at $t^{\circ} \ldots$. ). If Schwartz were to attempt to deprive the firm of the ability to borrow at $\ell^{\prime}$. the model would no longer be capable of proving his theory that "[a] set of contracts exists that will achieve the results described ... even though creditors lend at different times." Id.

53. See supra note 36 and accompanying text.

54. See supra note 37 and accompanying text.

55. See, e.g., Schwartz, supra note 3, at 1828 ("The lower the creditors" insolvency payoff, the less they will lend....").

56. See supra note 49 and accompanying text.

57. I propose this optimal fixing of the bribe in this second contract only to make clear that the firm achieves a net benefit by its deception at $t^{\circ}$ : It optimizes the retum from bankruptcy [y] and the percentage of that return [ $\left.s^{*}\right]$ in addition to obtaining its lending on more favorable terms.

58. See Schwartz, supra note 3, at 1824 (“[P]rivate benefits are assumed to be unverifiable."). Schwartz expressly states that "the paries cannot establish in court the monetary value of these benefits" and that "lending agreements . . cannot ban or regulate privale benefits by contract." Id. This might seem to leave open the possibility that the firm could verify the private benefits to creditors, with the result that deception would be impossible. This, however. clearly was not Schwartz's intention. First, Schwarz himself assumes that deception is possible under the model. See, e.g., id. at 1836 ("[T]he expected costs to the firm of offering later creditors 
conclusion is that no bankruptcy contracting will occur because the firm cannot "make a credible commitment to choose optimally" between reorganization and liquidation. ${ }^{59}$

Schwartz's second conversion term causes a malfunction of the bankruptcy contract that is closely analogous to that caused by the first conversion term. When the firm contracts with a second creditor, the second term provides that "the initial creditor's contract will convert (only as regards bankruptcy) to the contract type that is currently optimal for the firm." ${ }^{60}$ Schwartz gives the example that "[i]f it becomes optimal for the firm to offer the second creditor a renegotiation contract, the initial creditor's contract will convert to a renegotiation contract as well." ${ }^{61}$ Just as the first conversion term left the firm free to fix the bribe opportunistically in the first contract and to correct it in the second, this second conversion term leaves the firm free to fix the type of contract opportunistically in the first contract and to correct it in the second. The firm would choose the type of contract that appeared to give the first creditor the greatest expected return, borrow on the resulting favorable terms, and consolidate its gains by fixing the type of contract optimally in the firm's transaction with the second creditor. ${ }^{62}$

\section{STAGE THREE: CONTRACTING AMONG CREDITORS WITH INCONSISTENT PREFERENCES}

At the third stage, Schwartz seeks to expand his model to account for the possibility that "a firm's creditors may have inconsistent preferences concerning bankruptcy systems." ${ }^{63}$ For example, some creditors might prefer to pay a bribe for liquidation, while the other creditors might want to attempt reorganization. The concern is that such conflicts might be sufficient to prevent the parties from being able to agree to a single bankruptcy contract. Schwartz analyzes two possible sources of such conflict. The first is between junior and senior creditors; the second is between trade creditors and ordinary creditors.

inefficient contracts apparently would often outweigh the gains."). Second, if creditors had means of evaluating the firm's assertion that the bribe offered was optimal, the proof at stage one could have been much simpler. In any event, an assumption that the optimal percentage of the bribe was verifiable to one person (the creditor) but not to another (the judge) would be implausible.

59. Id. at 1826 .

60. Id. at 1834 .

61. Id.

62. Schwartz's use of the phrase "only as regards bankruptcy" makes clear with respect to the second conversion term that terms of lending other than the type of contract do not change on conversion. Id.

63. Id. at 1833 . 


\section{A. Conflict Between Junior and Senior Creditors}

Schwartz acknowledges the conventional wisdom that senior creditors generally favor liquidation while juniors favor reorganization. ${ }^{64}$ But he attributes this clash in preferences to the failure of the current bankruptcy system to respect absolute priority. To continue the development of his model into its third stage, Schwartz "assumes this conflict away by supposing that systems $R$ [reorganization] and $L$ [liquidation] both pay claims strictly in order of priority." ${ }^{6 S}$ Schwartz concludes that this assumption solves the problem of inconsistent preferences so that the firm's optimal choice between reorganization and liquidation will also be optimal for junior creditors. ${ }^{66}$ To explain this preference, he offers the following formula:

$$
p_{j}=\max \left(y_{1}-p_{s}, 0\right)
$$

In ordinary language, junior creditors recover $[p]$ the higher of (1) the bankruptcy return $[y$,$] less the amount paid to senior creditors [p$,$] , and (2)$ zero. From his formula Schwartz concludes that "[ $t$ ]herefore, the junior creditor wants the firm to choose whichever system maximizes the monetary return." 67

Schwartz errs, however, in assuming that deviations from the absolute priority rule are the sole cause of the well-known conflict between senior and junior creditors over the reorganization/liquidation choice. To see that the conflict would remain even in a system that paid claims strictly in accord with absolute priority, consider the following hypothetical. ${ }^{65}$ At the time it must choose between liquidation and reorganization $\left[l^{3}\right]$, the firm owes $\$ 100$ to senior creditors and $\$ 200$ to junior creditors. If the firm is liquidated, the monetary return $[y]$ will be $\$ 100$. If the firm attempts reorganization, there is a $40 \%$ chance of success, in which case the firm will be worth $\$ 200$, and a $60 \%$ chance of failure, in which case the firm will

64. See id. at 1836-37 ("[S]enior creditors today commonly prefer firms to use Chapter 7 . whether liquidation would be efficient or not, while junior creditors commonly prefer firms to use Chapter 11, whether reorganization would be efficient or not.").

65. Id. at 1837. The apparent logic in making this assumption is Schwarz's further assumption that an amendment to the bankruptcy law could mandate adherence to absolute priority in reorganization cases. I accept both assumptions for purposes of this argument.

66. See id. ("If absolute priority is respected, junior creditors would prefer the firm to choose the system that maximizes the monetary return, because they are paid nothing until claims senior to theirs are paid in full.").

67. Id. at 1837 n.70.

68. This hypothetical is based loosely on the facts of In re Central Ice Cream Co., 59 B.R. 476 (Bankr. N.D. Ill. 1985). 
be worth nothing. Thus, the mean value of the expected return from reorganization will be only $\$ 80 .^{69}$

Because the expected return from liquidation $(\$ 100)$ exceeds the mean value of the expected return from reorganization $(\$ 80)$, liquidation would maximize social welfare. The junior creditors, however, will prefer reorganization because they can expect a larger recovery $[p$,$] in$ reorganization than they would receive in liquidation. That is, in liquidation the junior creditors would recover nothing; in reorganization they would have a $40 \%$ chance of recovering $\$ 100-$ a mean bankruptcy return to junior creditors of $\$ 40$. This conflict persists even though distributions are governed by the absolute priority rule.

Apparently understanding this, Schwartz acknowledges in a footnote that his "analysis holds, though, only if the junior creditor focuses on the mean bankruptcy return." ${ }^{70}$ As Schwartz also realizes, however, the junior creditor has no reason to focus on the mean bankruptcy return to all creditors $\left[y_{t}\right]$ - the junior creditor is only interested in the mean bankruptcy return to the junior creditor, which is the mean bankruptcy return to creditors in excess of the senior creditor's payoff $\left[y_{1}-p_{s}\right]$. Schwartz acknowledges this as well, when he admits that "[i]t can be shown that the junior creditor would prefer a system with a lower mean return and a higher variance if the junior creditor would expect to receive nothing even under high realizations of the high mean procedure." ${ }^{71}$ In ordinary language, this sentence means that junior creditors would prefer an ill-advised reorganization in which they might get lucky (a "system with a lower mean return and a higher variance") if the junior creditors would recover nothing in a liquidation that produced greater overall value ("high realizations of the high mean procedure"). Schwartz closes his discussion by pleading ignorance as to how often this conflict would manifest itself in practice. ${ }^{72}$ In so doing, he ignores a substantial literature dealing with the conflict, ${ }^{73}$ a

69. This is calculated as follows: $(.4 \times \$ 200)+(.6 \times \$ 0)=\$ 80$.

70. Schwartz, supra note 3 , at 1837 n.70.

71. Id.

72. See id. ("It is unclear how common this preference would be in practice.").

73. The seminal work is part of a book by Fama and Miller. See EuGENE F. FAMA \& MERTON H. MILleR, THE THEORY OF FINANCE 178-81 (1972) (noting the conflict between creditors and shareholders regarding investment policy). Much of the literature deals with conflicts between creditors and shareholders rather than creditors inter se. See, e.g.. Jeremy I. Bulow \& John B. Shoven, The Bankruptcy Decision, 9 BELL J. ECON. 437, 439-40 (1978): Michael C. Jensen \& William H. Meckling, Theory of the Firm: Managerial Behovior, Agency Costs and Ownership Structure, 3 J. FIN. ECON. 305, 334-37 (1976). But when a company is insolvent, the junior creditors occupy the position of shareholders and the same principles apply. See Barry E. Adler, Bankruptcy and Risk Allocation, 77 CoRnEll L. REV. 439.443 (1992) ("On the eve of an insolvent debtor's bankruptcy, junior claimants have little to lose and much to gain if they invest the debtor's assets in a risky venture. Thus the junior claimants have an incentive 10 take untoward risks with the troubled firm's assets. Senior claimants, in contrast, bear the risk that such an investment will fail and do not share the junior claimant's incentives."); Lynn $M$. LoPucki \& William C. Whitford, Corporate Governance in the Bankruptcy Reorganization of 
consensus among judges and practitioners that the conflict is inherent and pervasive in the choice between reorganization and liquidation, ${ }^{74}$ and a vast body of empirical evidence suggesting that junior creditors generally recover nothing in liquidation. ${ }^{75}$ The case in which Schwartz's proposed solution fails is not some rarity; it is the norm.

The consequence of this failure for Schwartz's model is that neither a junior nor a senior ${ }^{76}$ creditor could be counted on to seek maximization of the value of the firm at the time of bankruptcy contracting. Bankruptcy contracts would tend to fix the bribe either too high or too low, depending upon whether the particular contract was with a junior creditor or a senior creditor.

The Coase Theorem tells us that in a world of perfect markets and zero transaction costs, the conflict between junior and senior creditors would be resolved by a contract between them that maximized the value of the estate and divided the increase in value thus attained between them in such a manner that each would be better off. ${ }^{77}$ Here the contract would be one

Large, Publicly Held Companies, 141 U. PA. L. REV. 669.683-84 (1993) (illustrating the conflict between "senior" and "junior" interests in a similar example, without respect to whether the juniors are creditors or shareholders).

74. See, e.g., In re SPM Mfg. Corp., 984 F.2d 1305. 1317 (5th Cir. 1993) (" While secured creditors might generally prefer liquidation and unsecured creditors might generally support reorganization, the Code surely does not require them to take such positions." ); In re Senescape Cruises, 131 B.R. 241, 242 (Bankr. S.D. Fla. 1991) ("The Debtor argues that the several members of the Committee who hold maritime liens are secured creditors who do not fairty represent the interests of unsecured creditors; that a conflict of interests exists within the Committec, since the maritime lien claimants would necessarily consider it in their own best interest to resist the Debtor's efforts to reorganize because they will more likely fare belter from the liquidation of the Debtor."); In re Cohoes Indus. Terminal, 65 B.R. 918, 921 (Bankr. S.D.N.Y. 1986) (" [T] his case does not present the usual conflict between the interests of the debtor and those of secured and unsecured claimholders. Here the secured claimholders, Leon and Gloria Baker and their related entities, control the debtor and seek to continue a joint effort to effect a reorganization."): In re Sweetwater, 40 B.R. 733, 737 n.10 (Bankr. D. Utah 1984) (quoting expent testimony that "[t]he fundamental conflict in all of this area is the struggle between secured creditors and the debtor or unsecured creditors because they usually side with the debtor on this question. as to how long he is going to be given to try to rehabilitate, reorganize and how quickly are you going to allow the secured creditor to realize on its collateral" (alteration in original)).

75. See, e.g., U.S. GEN. ACCOUNTING OFFICE, BANKRuptCY AdMINISTRATION: Case RECEIPTS PAID TO CREDITORS AND PROFESSIONALS 1, 5 (1994) (showing unsecured creditors as recovering nothing in $42 \%$ of asset-case Chapter 7 bankruptcies, which amounts to $97 \%$ of all liquidating bankruptcies); Roben M. Lawless \& Stephen P. Ferris. Professional Fees and Other Direct Costs in Chapter 7 Business Liquidations, 75 WASH. U. L.Q. 1207. 1218 (1997) ("In the vast majority of our chapter 7 business cases, the bankrupt firms had nothing left over after paying the costs of administering the case and distributing collateral to secured creditors." ); Lynn M. LoPucki, The Debtor in Full Control-Systems Failure Under Chapter $1 /$ of the Bankruptcy Code?, 57 AM. BANKR. L.J. 247, 255 (1983) ("Debtors" disclosure statements in the [Chapter 11] cases studied almost invariably asserted that the unsecured creditors should accept the debtor's proposal to continue operation because they would receive nothing in liquidation.").

76. Though I have analyzed only the interests of junior creditors, a similar analysis of the incentives of senior creditors would show that they have an inherent bias in favor of liquidation.

77. See, e.g., Daniel A. Farber, Parody LostPragmatism Regained: The Ironic History of the Coase Theorem, 83 VA. L. REV. 397, 401 (1997) ("According to the Coase Theorem. assuming that transaction costs don't prevent contracting around legal nules, the legal rules don't matter-or 
between junior and senior creditors in which earlier creditors bribed the most recently arrived creditor to fix an optimal bribe for the firm. The problem Schwartz set out to solve, however, was how the parties could arrive at an optimal bankruptcy contract, not in a world of perfect markets and zero transaction costs, but in the world of his assumptions. In that world, creditors arrive at different times and have no means of bribing one another because they never negotiate with one another.

\section{B. Conflict Between Trade and Ordinary Creditors}

The second source of conflict among creditors that Schwartz considers is that trade creditors, who profit by selling additional merchandise to the debtor during a reorganization effort, have an ulterior motive that might cause them to favor "wasteful reorganization." ${ }^{78}$ Because profits from the additional sales would distort their incentives in favor of continuing the business, these creditors "would be unwilling to bribe the firm to choose system $L$ when $L$ turned out to be optimal for creditors as a group." 74 Schwartz's solution to the problem is to permit "majority rule ... to govern the contracting process." ${ }^{80}$ Schwartz's reference to the "ex ante majority" ${ }^{81}$ makes clear that the majority is to be determined by elections in bankruptcy contracts, not in a vote taken after the bankruptcy case is filed.

Schwartz's solution to the trade-creditor problem has three serious defects, any one of which would render it unworkable. First, it is inconsistent with his solution in the second stage to the problem of creditors lending at different times. Recall that when the initial creditor contracted with the firm at time $t^{0}$, and a second creditor contracted with the firm at time $t^{\prime}$, Schwartz proposed that the bribe in the first creditor's contract would convert to the bribe in the second creditor's contract. ${ }^{82}$ Schwartz now apparently proposes that the same issue is to be resolved by majority vote instead. He cannot have it both ways if his solution is to operate in the real world.

Second, Schwartz gives no clue as to how he would count the votes. Assume, for example, that the firm's three creditors contracted to fix the bribe percentage $[s]$ at $30 \%, 35 \%$, and $40 \%$, respectively. One might count

more precisely, the parties will always bargain their way to an economically efficient outcome, regardless of the legal rule."); Lynn M. LoPucki, Strange Visions in a Strange World: A Reply to Professors Bradley and Rosenzweig, $91 \mathrm{MICH}$. L. REV. 79, 106 (1992) (stating the theorem as follows: "In the absence of transaction costs, parties will reach an agreement that maximizes joint wealth.").

78. Schwartz, supra note 3 , at 1838.

79. Id.

80. Id.

81. Id.

82. See id. at 1834 . 
this as a mere failure of the voting process because no proposed bribe percentage $[s]$ received a majority vote. Alternatively, one might average the three votes to fix the bribe percentage $[s]$ at $35 \%$ or take the median to reach the same result. Considering Schwartz's assumption that "which contract would be optimal can be time variant," 83 if the three creditors contracted with the debtor at different times the most reasonable supposition might be that the optimal amount of the bribe increased with the passage of time and is now $40 \%$. But that supposition leads to the conclusion that voting can be an appropriate solution only if all creditors vote at the same time. Schwartz offers no mechanism by which the creditors, who he assumes arrive at different times, could do that.

Third, Schwartz's proposal of majority rule implicitly assumes that the creditors who prefer an efficient liquidation will outnumber those who prefer an inefficient reorganization. Probably in most cases, the reverse will be true: The firm will have a single "objective" bank lender and a large number of trade creditors who are biased in favor of reorganization. Even if the voting is by dollar amount of claims, the trade creditors will hold a blocking position in many cases. ${ }^{84}$ The current system works because it does not rely on voting to make the choice between reorganization and liquidation. Instead, it employs a procedure that is anathema to Schwartz:: having a bankruptcy judge determine whether the value of the company is higher in reorganization or liquidation. ${ }^{86}$

In the third stage of his model, Schwartz deliberately ignores the conflict between contract creditors, who have the opportunity to contract with the debtor, and involuntary creditors, who do not. ${ }^{87}$ As to the specific issue Schwartz models-the choice between reorganization and

83. Id. at 1833.

84. Chapter 11 voting procedures, which Schwarz apparently would adopt by reference. require more than two-thirds of the creditors in a class to vote in favor before the class is considered to have accepted. See 11 U.S.C. $\$ 1126$ (c) (1994). The purpose of this requirement is to prevent a simple majority from imposing its plan on an opposing minority that is essentially as large. Schwartz does not indicate whether he would abandon this longstanding rule.

85. See, e.g., Schwartz, supra note 3, at 1818 ("Local communities know more than bankruptcy judges can know about the public benefits of saving particular firms. Therefore local communities will make more accurate continuation decisions than bankruptcy courts will." ).

86. Under the "best interests of creditors" test in 11 U.S.C. $\S 1129(a)(7)$, the coun can confirm a plan of reorganization only if the court concludes that every creditor will receive under the plan at least as much value as it would receive in liquidation. Logically, the coun can make such a finding only if the court finds that reorganization will produce at least as much value as liquidation.

87. See Schwartz, supra note 3, at 1810 n.15 ("'Tort and environmental victims of the firm's activities do not bargain with the firm ex ante, but do have current bankruptcy claims against it. These claims should be protected in bankruptcy, but just how is beyond this Essay's scope."). In an earlier article, Schwartz indicated a belief that conflicts between tort and contract creditors are unimportant because nearly all tort liability is covered by insurance. See Alan Schwartz. A Theory of Loan Priorities, 18 J. LEGAL STUD. 209, 259 (1989). That belief is unfounded. See. e.g., Lynn M. LoPucki, The Unsecured Creditor's Bargain, 80 VA. L. REV. 1887. 1906 n.81 (1994) (providing examples of large firms having uninsured tor liability in excess of their ability to pay). 
liquidation-at least two sources of conflict are apparent. First, involuntary creditors whose claims have not yet been reduced to judgment may tend to prefer reorganization so that they can litigate the amounts of their claims against the representatives of "guilty," subordinate shareholders rather than against the "innocent" holders of other unsecured claims. ${ }^{88}$ Second, future involuntary creditors-those who will be injured after bankruptcy by wrongful acts the debtor committed before bankruptcy — might tend to fare better if the business were preserved as a going concern that remained liable for future claims, while voluntary creditors might tend to prefer an immediate liquidation that estimated the future claims and reserved some of the proceeds to pay for them or that liquidated the firm and distributed the proceeds before involuntary creditors suffered their injuries and sued. ${ }^{89}$

These conflicts are of sufficient importance and complexity that bankruptcy courts have appointed representatives ex post to protect the interests of future claim holders. ${ }^{90}$ If present creditors could make the critical decisions regarding bankruptcy procedure in ex ante contracts, they could freeze future claimants out of the decisionmaking process altogether. Appointing future claims representatives ex ante to participate in the bankruptcy contracting is not a possible solution for three reasons. First, no institutional mechanism exists for identifying the situations in which such appointments would be necessary or for making them. Second, appointments would have to be made for all firms that might have future claims liability, including firms not in financial difficulty. Finally, even if that expense were warranted, the representatives appointed could not exercise the power that balances and legitimates ex ante bankruptcy contracting: the power to refuse to extend credit.

When proposals for bankruptcy contracting extend beyond the reorganization/liquidation decision Schwartz explores in his model, the conflicts between voluntary and involuntary creditors multiply. ${ }^{91}$

88. That is, the finder of fact is likely to be more generous with a tort creditor whose recovery will come from the debtor in reorganization than with a tort creditor whose recovery will come from the distributions that otherwise would go to other creditors. For a reflection of this prejudice in current bankruptcy law, see 11 U.S.C. \$ 726(a)(4), which subordinates claims for exemplary and punitive damages to the claims of unsecured creditors generally, but only in Chapter 7 liquidations.

89. Indeed, asset-securitization transactions, discussed in the next Part, can be viewed as preinsolvency liquidations that contract creditors demand in part to assure their priority over lateraccruing involuntary claims. The securitization contract assures that the business can continue despite the liquidation of its assets.

90. See, e.g., Ralph R. Mabey \& Jamie Andra Gavrin, Constitutional Limitations on the Discharge of Future Claims in Bankruptcy, 44 S.C. L. REv. 745, 757 n.46 (1993) (listing cases in which bankruptcy courts have appointed future claimants' representatives).

91. Other scholars who have addressed the conflict between tort and contract creditors have generally proposed to resolve the conflict by subordinating contract creditors, including secured creditors, to tort creditors. See LoPucki, supra note 87, at $1908 \mathrm{n.88}$ (citing endorsements of tortcreditor priority by Professors Barry Adler, David Leebron, Robert Rasmussen, and Mark Roc). Despite the endorsement of such well-respected scholars, lawmakers are unlikely to subordinate 
Ultimately, these conflicts may be impossible to resolve in any scheme of bankruptcy contracting. Until that is determined, scholars should consider bankruptcy-contract "solutions" that do not address the conflicts between voluntary and involuntary creditors to be partial or, better yet, incomplete.

\section{DOES BANKRUPTCY CONTRACTING SEEK EFFICIENCY OR MERELY REDISTRIBUTION?}

Schwartz posits at the outset that the kinds of bankruptcy contracts he discusses are currently illegal. ${ }^{92}$ This premise serves two functions in his argument. First, it suggests that the stakes are large: If Schwartz could prove bankruptcy contracting efficient, the proof would establish the need for a change in current law. ${ }^{93}$ Second, his premise excuses him from the need to present empirical evidence of a demand for the right to contract for bankruptcy procedure. If bankruptcy contracts are illegal, no such evidence could exist. ${ }^{94}$

Schwartz's premise is wrong in two respects. First, although courts have refused to enforce some kinds of bankruptcy contracts as violative of "public policy," their statements are generally dicta; the issue has rarely been addressed in binding precedent. ${ }^{95}$ At least one commentator believes that bankruptcy contracts are not currently illegal; that is, he believes that the courts would enforce appropriate bankruptcy contracts presented to them. ${ }^{96}$

secured creditors to tort creditors, making the prospects for an efficient scheme of bankruptcy contracting similarly remote. See, e.g., Steven L. Harris \& Charles W. Mooncy. Jr., Measuring the Social Costs and Benefits and Identifying the Victims of Subordinating Securin Imerests in Bankruptcy, 82 CORNELL L. REV. 1349, 1371 (1997) ("As a political matter, the subordination proposals have no realistic prospects for widespread suppor and adoption.").

92. "[P]arties cannot contract in lending agreements to use a bankruptcy system other than the one the state supplies." Schwartz, supra note 3, at 1808. "Firms today cannot finance projects that they would be able to finance if the ban were repealed." Id. at 1832.

93. See id. at 1812 (claiming as part of his essay"s contribution "a demonstration that parties could solve their coordination problem at the credit extension stage and so would write efficient 'bankruptcy contracts' if they were free to do so").

94. See id. at 1833 ("Because bankruptcy contracts are currently illegal, there is no data about real contracts that could support this argument.").

95. See Marshall E. Tracht, Contractual Banknuptcy Waivers: Reconciling Theory. Practice, and Law, 82 CORNELL L. REv. 301,306 (1997) ("Although numerous cours have commented in dicta on the unenforceability of a firm's waiver of the right to file bankruptcy. few cases actually raise the issue and none analyze it."). No precedent regarding prepetition bankruptcy waivers by corporations appears to exist above the district coun level. See id. at 305-09.

96. See id. at 349 ("The Code does not prohibit a firm from waiving its right or restricting its ability to file a voluntary petition, or from waiving the automatic stay."): $i d$. at 305-09 (arguing that none of the cases on which the courts relied addresses the enforceability of a contractual waiver of bankruptcy rights or explains how bankruptcy waivers violate bankruptcy policy); $i d$. at 303 ("This Article challenges the accepted view that bankruptcy waivers are unenforceable under the Bankruptcy Code."); see also Schwarcz. supra note 2, at 600 ("I have shown that when a debtor and all of its creditors agree to a procedure contract, there is litule question that the contract should be enforced."). But see Tracht, supra note 95, at 305 ("Although there is litte case law on 
Second, legal strategies are often capable of achieving results that appear impossible on the face of legal doctrine. ${ }^{97}$ This has already occurred to some degree with respect to bankruptcy contracting. ${ }^{98}$ As Professor Marshall Tracht observes, aggressive lawyers have devised a wide variety of strategies to enable willing debtors and their creditors to opt out of the state-supplied bankruptcy system. ${ }^{99}$ The following list illustrates the broad range and power of these strategies:

1. Locking control. A corporate debtor can file bankruptcy only if its board of directors authorizes it to do so. ${ }^{100}$ Creditors prevent the necessary authorization by contracting ex ante for a provision in the debtor's corporate charter that requires the affirmative vote of all directors to authorize a bankruptcy filing or to authorize a change in the charter provision. The charter provision distributes voting power in the corporation such that at least one of the directors elected will not vote in favor of a bankruptcy filing not approved by creditors. ${ }^{101}$ For example, the charter might allow creditors to appoint a director, ${ }^{102}$ it might authorize a voting proxy in favor of one or more creditors; ${ }^{103}$ or it might require the appointment of a director with fiduciary duties to creditors..$^{104}$

2. Voting debt. The bankruptcy contract provides that upon specified events of default, creditors have the option to convert a portion of their debt

this question, courts seem to accept, almost as a matter of faith, that commercial agreements waiving the right to file for bankruptcy are unenforceable.").

97. See Tracht, supra note 95, at 302 ("Thus, we have created a situation in which both theory and practice are increasingly at odds with the established view of the law-a conflict which has gone largely unaddressed in the legal literature."); Lynn M. LoPucki \& Walter O. Weyrauch. A Theory of Legal Strategy (Aug. 20, 1999) (unpublished manuscript, on file with The Yale Law Journal) (arguing that conventional legal theory misleads by ignoring the ability of legal strategy to transform legal doctrine).

98. See Tracht, supra note 95, at 302 (" [C]orporate and bankruptcy lawyers have become increasingly adept at designing techniques that keep firms from utilizing the bankruptcy laws without nunning afoul of the law's hostility to [bankruptcy] waivers.").

99. See id. at 309-11 (describing strategies for bankruptcy-proofing); see also LYNN M. LOPUCKI, STRATEgIES FOR CREDITORS IN BANKRUPTCY PROCEEDINGS 186-87 (3d ed. 1997) (describing strategies for "bankruptcy-proofing the debtor corporation").

100. See, e.g., In re Runaway II, Inc., 159 B.R. 537, $537-38$ (Bankr. W.D. Mo. 1993) (dismissing a corporate bankruptcy petition because the filing was not authorized by its board of directors); In re Giggles Restaurant, 103 B.R. 549, 553 (Bankr. D.N.J. 1989) (“[1]t is clear that any corporate resolution which authorizes the filing of a voluntary bankruptcy petition must originate at a validly held meeting of directors and must be approved by the proper number of such directors.").

101. See, e.g., LoPuckI, supra note 99, at 186; Christopher T. Katucki, Make Your Next Workout Bankruptcy Remote, BANKR. CT. DECISIONS, Nov. 19, 1996. at 3 (suggesting that the debtor's charter be amended to require the affirmative vote of all directors for a bankruptcy filing).

102. See, e.g., In re Kingston Square Assocs., 214 B.R. 713, 716-17 (Bankr. S.D.N.Y. 1997) (stating that charters made debtors "bankruptcy proof" by prohibiting debtors from seeking bankruptcy without the unanimous consent of the board of directors, including an "independent" director whose fees were paid by the mortgage holder).

103. See Tracht, supra note 95, at 309.

104. See infra text accompanying note 120 . 
into shares of stock that have voting control of the debtor corporation. ${ }^{105}$ The creditors, as controlling shareholders, then decline to file bankruptcy or dismiss a bankruptcy already filed. In a variation of this technique, the creditors take a security interest in the controlling stock of a debtor corporation to secure the corporation's obligations. In the event of default, the creditors foreclose on the stock to take control of the debtor corporation. ${ }^{106}$

3. Leverage through personal guarantees. The bankruptcy contract provides for personal guarantees by the owners of the debtor firm that, by their terms, operate only in the event that the corporation files bankruptcy without the consent of the creditors. ${ }^{107}$ Such an executory contract is not an ipso facto provision unenforceable under $\S 365(\mathrm{e})(1)$ of the Bankruptcy Code because it is not an executory contract of the debtor (corporation). ${ }^{103}$ Making the guarantees in the form of standby letters of credit can virtually eliminate any doubts as to the enforceability of such "springing" or "exploding" guarantees. ${ }^{109}$

4. Isolation of collateral. The bankruptcy contract provides that the collateral will be held by an entity separate from that conducting the main operations of the debtor so that the stay will not bar foreclosure if the main entity goes into bankruptcy. ${ }^{110}$ The isolated entity can also be bankruptcyproofed, using one of the other methods."

5. Bankruptcy-ineligible entities. Trusts that are not business trusts are ineligible to file for bankruptcy. Placing assets in such a trust prevents the assets from falling into bankruptcy. ${ }^{112}$

Each of these devices meets Schwartz's criteria for bankruptcy contracting: They can be part of the initial lending agreement; they can be employed on behalf of the debtor and creditors as a group; and they can prevent the debtor from filing bankruptcy without the consent of the creditors. Creditors who can prevent bankruptcy entirely can, of course,

105. See LoPucKI, supra note 99 , at 186.

106. See, e.g., In re Advanced Ribbons and Office Prods., 125 B.R. 259. 260 (B.A.P. 9th Cir. 1991) (awarding creditors possession and control of debtor corporation through a postpetition foreclosure against stock of the debror corporation); A.D.M. Corp. v. Thomson. 707 F.2d 25. 28 (1st Cir. 1983) (upholding a secured creditor's purchase of controlling stock in the debtor at the secured creditor's own foreclosure sale over objections based on federal securities laws).

107. See LOPUCKI, supra note 99, at 187.

108. See id.

109. See Tracht, supra note 95, at 313-14.

110. See LOPUCKI, supra note 99 , at 186-87.

111. See, e.g., In re Kingston Square Assocs., 214 B.R. 713 (Bankr. S.D.N.Y. 1997) (involving real estate collateral separated among numerous corporations, each bankruptcy-proofed by means of a control provision).

112. See Henry Hansmann \& Ugo Matei, The Funcrions of Trust Law: A Comparative Legal and Economic Analysis, 73 N.Y.U. L. REV. 434, 468 (1998) (noting the frequent use of trusts to achieve bankruptcy remoteness in asset-securitization transactions); Tracht, supra note 95, at 309. 
condition bankruptcy. That opens the door for some kinds of bankruptcy contracting. ${ }^{13}$

It is difficult to estimate how often creditors employ these strategies to contract for bankruptcy procedure. When employed successfully, the result is usually that the debtor remains outside bankruptcy; no court has occasion to write an opinion; and the existence of the contract remains known only to the parties. ${ }^{114}$ Only the clumsiest ${ }^{115}$ and most egregious ${ }^{116}$ are challenged in court and risk exposure in published opinions.

Repeat participants, however, have sometimes indicated the broader patterns of bankruptcy contracting. These indications suggest two areas in which bankruptcy contracting is widespread. First, waivers of the automatic stay are now routinely inserted into workout agreements, particularly those dealing with single-asset real estate. ${ }^{17}$ Second, strategic "bankruptcy proofing" devices appear to be in widespread use in the booming assetsecuritization market. ${ }^{118}$

In an article that described the $\$ 200$ million securitization of some of Sea Containers, Ltd.'s marine cargo containers, James Gadsden-whose firm, Carter, Ledyard \& Milburn, represented Sea Containers, Ltd. at the

113. Once creditors permit their debtor to file in the state-supplied bankruptcy system, no contractual restriction reliably can prevent that debtor from using the entire range of options available to debtors in that system. A court can declare any restriction void as in violation of the public policy barring bankruptcy contracts. See, e.g., 11 U.S.C. $\$ 706$ (1994) (granting Chapter 7 debtors the right to convert their cases to Chapter 11 and specifically providing that waiver of the right is unenforceable).

114. See Tracht, supra note 95 , at 314 ("If disincentives succeed in their objective, they leave little or no trace in the law records. Debtors who 'go gentle into that good night' rather than file for bankruptcy do not show up in the case books or bankruptcy statistics."). Secrecy may provide an important reason for society to reject contract solutions. The problems with regulation occur publicly and are therefore subject to examination and correction through the political process. The problems with contract occur privately and can be examined only to the extent that contracting parties volunteer information or the state requires disclosure. The latter is unlikely to occur unless some question is first raised regarding the particular type of contracting.

115. See, e.g., Kingston Square Assocs., 214 B.R. at 713 (involving a mortgage holder who selected and paid the fees of an "independent" director who had authority, under a provision in the charter, to veto a bankruptcy filing). The device was exposed in court only because the debtor managed to get into bankruptcy by soliciting unsecured creditors to file an involuntary petition against it. See id. at 737 ("The Debtors and the Petitioning Creditors orchestrated the filing of these involuntary cases to evade what they perceived to be an insurmountable restriction against the Debtors' filing voluntary petitions.").

116. See cases cited infra note 128 .

117. See, e.g., Daniel B. Bogart, Games Lawyers Play: Waivers of the Automatic Stay in Bankruptcy and the Single Asset Loan Workout, 43 UCLA L. REV. 1117, 1134, 1226-27 (1996) (describing the spread of stay waivers based on interviews and examination of the practitioner literature); Jeffrey W. Warren \& Wendy V.E. England, Pre-Petition Waiver of the Automatic Stay Is Not Per Se Enforceable, AM. BANKR. INST. J., Mar. 1994, available in LEXIS, Lawrev Library, ABIJ File, at *1 ("Practically every loan modification or business workout agreement drafted today contains a series of boilerplate "bankruptcy waiver' provisions.").

118. James Gadsden, What the Credit Analyst Should Know About Securitization, Bus. CREDIT, Mar. 1998, at 54, 56. 
time ${ }^{119}$-also described the steps generally taken to assure that a corporation established to own securitized assets (the "Special Purpose Vehicle," or the "SPV") could not enter the state-supplied bankruptcy system. They are:

seeking agreements from all parties that deal with the SPV, including the parties to the securitization financing, that they will not initiate a bankruptcy case against the SPV, [and] requiring the appointment to the board of directors of an independent director charged with fiduciary duties to the creditors. The independent director's consent is required to initiate a bankruptcy case and is expected to be withheld if the only benefit of the bankruptcy filing is to assist the [corporation that originated the transaction]. ${ }^{120}$

The concern addressed in the last sentence of this provision is that the assets of the SPV might be drawn into the bankruptcy of the originator. Commentators all agree that the "bankruptcy remoteness" of the SPV is essential to the securitization transaction. ${ }^{121}$ They dispute, however, what the parties gain by keeping the assets of the SPV out of the originator's bankruptcy. Some argue, consistent with Schwartz's position, that the purpose is merely to avoid the inefficiency of bankruptcy. ${ }^{122}$ One effect of asset securitization, however, is to shift the risks of the originator's business away from investors and to impose them on involuntary or non-adjusting creditors such as taxing authorities, employees, and creditors injured by the debtor's business practices. ${ }^{123}$ By spinning off a portion of its assets in the SPV, the debtor reduces the total assets exposed to the risks of its business and the claims of its future, non-adjusting creditors. ${ }^{124}$ The benefits to originators and investors may, in at least some asset securitizations, derive entirely from that risk shifting.

119. See SEA CONTAINERS, LTD., FORM 10-K FOR THE YeAR ENDING DeCEMBER 31, 1997. pt. III, item 13, para. 3 (1998).

120. Gadsden, supra note 118, at 56: cf. Tracht, supra note 95, at 310-11 (discussing securitization and concluding that bankruptcy-proofing of "special purpose vehicles" has "been largely but not entirely successful").

121. See, e.g., Steven L. Schwarcz, The Alchemy of Asset Securitization, I STAN. J.L. BuS. \& Fin. 133, 135 (1994) ("The SPV, however, must be structured as "bankruptcy remote' to gain acceptance as an issuer of capital market securities.").

122. See, e.g., Christopher W. Frost, Asset Securitization and Corporate Risk Allocation. 72 TUL. L. REV. 101, 129 (1997) ("If the bankruptcy process is an inefficient means of making the asset deployment and distributional decisions raised by financial distress, assct securitization may be a means by which all investors could make a binding promise to avoid the process (at least with respect to the securitized assets).").

123. See Lynn M. LoPucki, The Death of Liabiling. 106 YALE LJ. 1. 23-30 (1996) (explaining how asset securitization accomplishes a shift of business risk from investors to nonadjusting creditors).

124. See id. 
Schwartz excludes prepetition waivers of the automatic stay from his concept of bankruptcy contracting, apparently because the contracting occurs after insolvency rather than at the time of the lending agreement. ${ }^{125}$ While this exclusion may be warranted by the nature of Schwartz's proposal, ${ }^{126}$ it prevents him from noticing a pattern in the stay-waiver cases that has ominous implications for bankruptcy contracting.

In nearly all cases, the stay-waiver contracts are merely between the debtor and a single, dominant secured creditor. ${ }^{127}$ The agreement of the unsecured creditors is never solicited. ${ }^{128}$ Courts that reject these devices give a variety of reasons, but the most common is to avoid prejudice to nonsigning unsecured creditors. ${ }^{129}$ That secured creditors do not obtain the agreement of unsecured creditors in so many of these cases suggests that the goal of this contracting is not efficiency, but merely redistribution of wealth from unsecured to secured creditors. ${ }^{130}$ That is, the stay waiver is a

125. See Schwartz, supra note 3 , at 1840 ("[T]he firm cannot waive its right to stay collection in the lending agreement.").

126. Schwartz's solution to the problem of contracting-that the debtor disclose the amount of the optimal bribe $\left[s^{\circ}\right]$ and the parties contract for it because it is in both their interests-only works at the time of the initial loan. By contrast, stay waivers are generally used only after insolvency; waivers given at the time of the loan are generally thought to be unenforceable. See. e.g., Tracht, supra note 95, at 345 (referring to the "practitioners' belief that initial waivers are not enforceable, but that waivers may be enforceable as part of an out-of-court workout").

127. But see In re Tru Block Concrete Prods., 27 B.R. 486 (Bankr. S.D. Cal. 1983) (refusing to enforce a prepetition agreement not to file bankruptcy even though substantially all creditors had signed). Asset securitizations follow Rasmussen's model more closely than Schwartz's model in that the relevant provisions are placed in the charter of the SPV. However, no renegotiation over time is contemplated, and the originator's creditors-those disadvantaged by the transaction-need not be advised or consulted.

128. See, e.g., In re Pease, 195 B.R. 431, 434 (Bankr. D. Neb. 1996) (refusing to enforce a prepetition agreement between the debtor and a single creditor and noting that such enforcement "would permit a single creditor to opt out of the collective process mandated by the Bankruptcy Code to the potential detriment of the debtor and other creditors"); In re Madison, 184 B.R. 686. 690 (Bankr. E.D. Pa. 1995) (noting, in refusing to enforce a prepetition agreement between the debtor and a single mortgage lender, that the debtor would not refile bankruptcy for 180 days and that " [s]uch a temporary bar could harm competing creditors, as it could provide one creditor with an unfair advantage, such as providing that creditor with sufficient time as to avoid the [statutory] preference period"); In re Cheeks, 167 B.R. 817 (Bankr. D.S.C. 1994) (enforcing a prepetition agreement with only a single creditor, but only because no other creditor objected); Farm Credit v. Polk, 160 B.R. 870, 873 (M.D. Fla. 1993) (noting that " [n]o other creditors were involved in the prepetition agreement" and refusing to lift the stay); In re Sky Group Int'l, 108 B.R. 86, 89 (Bankr. W.D. Pa. 1989) (refusing to lift the automatic stay in accordance with a prepetition agreement because none of the creditors who brought the involuntary petition was a party to the agreement); In re Adana Mortgage Bankers, 12 B.R. 989 (Bank. N.D. Ga. 1980) (refusing to enforce a covenant against bankruptcy filing made with only a single creditor).

129. See cases cited supra note 128. Absent prejudice to other creditors, the courts tend to enforce prepetition waivers. See, e.g., In re Club Tower L.P., 138 B.R. 307, 309 (Bankr. N.D. Ga. 1991) (holding a prepetition agreement enforceable in a case in which the debtor had "only a few unsecured creditors whose claims [were] de minimus"). But see In re Atrium High Point Ltd.. 189 B.R. 599, 608 (Bankr. M.D.N.C. 1995) (refusing to enforce a prepetition waiver actually agreed to by eight of the nine objecting creditors).

130. Stay waivers are the types of bankruptcy contracts for which it would be least expensive to seek the consent of all creditors. Secured creditors can obtain stay waivers during workouts. the point at which unsecured creditors can most easily be identified and solicited. 
means by which the secured creditor and debtor capture wealth that otherwise would go to unsecured creditors.

The current pattern of bankruptcy contracting may be motivated to some degree by considerations of efficiency. Yet these examples show that both types of bankruptcy contracting currently in wide use-asset securitizations and stay waivers - have the potential to redistribute wealth from noncontracting parties to contracting parties. By contrast, no evidence exists of any form of contracting that would protect all creditors, present and future-even though such contracts would have far greater appeal to the courts. ${ }^{131}$ This pattern suggests that the latter types of contracts may not offer sufficient benefits to justify the costs of making them.

Of course, the direction of bankruptcy contracting might change with de jure legalization. The costs of contracting might be lower and the results more certain. In such a world, the parties might choose different contracts than they do today. But the little evidence currently available suggests that the real-world appeal of bankruptcy contracts lies less in their capacity to maximize social welfare than in their capacity to redistribute wealth.

\section{CONCLUSION}

Based on his assumptions in the first stage of his model, Alan Schwartz proves bankruptcy contracting to be feasible in an environment in which all creditors contract with the firm simultaneously and all have identical rights. His solution is a contract that offers the debtor a bribe to file for liquidation that equals and offsets the private benefit the firm would gain by filing for reorganization. ${ }^{132}$

In the second stage of his model, Schwartz attempts to expand his solution to an environment in which creditors have identical interests, but contract at different times. His solution at this stage is a contract that fixes the bribe payable at bankruptcy according to the provisions of the firm's last contract with a creditor. ${ }^{133}$ That solution, however, would be unacceptable to an extender of credit unless that extender knew it would be the last. The debtor would have insufficient incentives to disclose to earlier extenders the information they would need to fix the bribe optimally. ${ }^{134}$ Contracting would fail, leaving Schwartz's entire model of "only theoretical interest." ${ }^{135}$

131. See, e.g., Schwarcz, supra note 2, at 600 ("Indeed. I have been unable to find any evidence of the existence of actual procedure contracts.").

132. See supra text accompanying notes $34-35$.

133. See supra text accompanying notes $45-46$.

134. See supra notes $47-51$ and accompanying text.

135. Schwartz, supra note 3 , at 1833 . 
Although the third stage of Schwartz's model is rendered moct by the failure of the second, his contracting solution at the third stage fails as well. In that stage, Schwartz attempts to expand his solution to an environment in which some creditors have priority over others and in which trade creditors have ulterior motives for favoring even ill-advised reorganization. As for the conflict between junior and senior creditors, Schwartz incorrectly assumes that amending the Bankruptcy Code to assure the seniors of absolute priority over the juniors in reorganization cases would eliminate it. ${ }^{136}$ As for the conflict between trade and other creditors, Schwartz proposes a contracting solution-majority rule-that conflicts with his solution to the contracting problem at stage two-the last contract governs. ${ }^{137}$ His solution also suffers from his failure to specify the nature of the majority required ${ }^{138}$ and his dubious assumption that trade creditors with ulterior motives would not be in the majority. ${ }^{139}$

Schwartz's failure to deliver a model of bankruptcy contracting that works does not mean that such a model is impossible. The purpose of Schwartz's model was to improve on Rasmussen's impractical, but admittedly workable, solution by lowering transaction costs. ${ }^{140}$ Although the first stage of Schwartz's model generates a contract that is optimal on the model's assumptions, this Essay demonstrates that the elegant mechanism by which it does so cannot operate in a world in which creditors lend at different times or under different circumstances. To improve on Rasmussen's solution will require an entirely new mechanism. Until that occurs, the theoretical case for welfare-maximizing contractual bankruptcy remains unproven. ${ }^{141}$

Practitioners report extensive contracting for bankruptcy procedure in two kinds of transactions: workouts and assets securitizations. Failure of secured creditors to include unsecured creditors in the contracts for stay waivers in workouts suggests that the contracting parties are attempting to appropriate the expectancies of the unsecured creditors rather than to maximize social welfare. ${ }^{142}$ Failure to protect the future creditors of the

136. See supra text accompanying notes $68-75$.

137. See supra text accompanying notes 80-82.

138. See supra text accompanying note 83 .

139. See supra note 84 and accompanying text.

140. See Schwartz, supra note 3, at 1811 (" [This solution] may founder over the problem that because the optimality of a bankruptcy system is state-dependent, it also can be time-dependent. Put more simply, time may render a company's charter solution outmoded, and corporate charters are inconvenient to amend."). Had Schwartz's model worked, no creditor would have had (o) concern itself with the contracting activity of any other-what Schwartz referred to as "the relative flexibility of using lending agreements to induce the choice of optimal bankruptcy systems." Id.

141. Based on other defects in proof, and without discussing the defect in proof described in this reply, Susan Block-Lieb had already reached the conclusion that the case for contract bankruptcy remains unproven by any scholar. See Block-Lieb, supra note 2, at 9-28.

142. See supra notes $127-130$ and accompanying text. 
originator in asset-securitization contracts suggests that redistribution of wealth may be the motivating force in those transactions as well..$^{143}$ These tendencies of real-world bankruptcy contracting to seize on opportunities for redistribution do not bode well for the future of bankruptcy contracting.

The case for freedom of contract rests squarely on the assumption that each party chooses the contract because the contract makes that party better off. Because each party is better off, all parties are better off in the aggregate. ${ }^{144}$ That aggregate then becomes a proxy for "social welfare." In the bankruptcy context, this theory holds that thousands of correct decisions by a debtor and each of its creditors and shareholders will generate one correct decision-the bankruptcy contract-in the aggregate. ${ }^{\text {iss }}$ That decision will maximize social welfare.

The principal problem in attempting to apply this theory in the context of bankruptcy is that most creditors' interests are too small to warrant their active, knowledgeable participation. The task of bankruptcy-contract promoters is to find justifications for treating these creditors as if they had participated knowledgeably. ${ }^{146}$ Thus, Alan Schwartz would bind every earlier creditor to the contract made by the last, on the theory that the earlier one would have made the same decision; ${ }^{147}$ Steven Schwarcz would bind creditors to bankruptcy-procedure contracts on the basis of actual agreement by "representative members of a similarly situated class," on the theory that "distributional effects on other members of the class are likely to be small"; 148 and Marshall Tracht would bind unsecured creditors to the stay waivers contracted by debtors with their secured creditors on the theory that the recoveries of unsecured creditors would have been de minimis anyway. ${ }^{149}$ Only Robert Rasmussen seems to contemplate requiring the agreement of all creditors for the validity of a bankruptcy

143. See supra text accompanying notes 123-124.

144. See, e.g., Robert C. Clark, Contracts, Elites, and Traditions in the Making of Corporate Law, 89 COLUM. L. REV. 1703, 1714 (1989) ("[T]he argument for contractual rule making is simple but powerful. . . . Contractually created rules will tend strongly to be pareto-superior rules: they will make one or both parties better off, and neither party worse off.").

145. In Schwartz's paradigm, only the preferences of creditors and sharcholders need be taken into account in measuring efficiency. See Schwartz, supra note 3, at 1817-19. I have accepted this paradigm only for purposes of argumentation. I agree with Professor Elizabeth Warren that the appropriate measure of social welfare takes into account the impacts of business activity on all affected persons. See Elizabeth Warren, Bankruptcy Policymaking in an Imperject World, 92 MicH. L. REV. 336, 356 (1993).

146. See Schwarcz, supra note 2, at 600 (" [A] procedure contract could work, as a practical matter, only if the law imposes a consensus mechanism that substitutes for unanimity.").

147. See supra text accompanying notes $80-82$.

148. Schwarcz, supra note 2 , at 602 n.467.

149. See Tracht, supra note 95 , at 354 ("With so little unsecured debt involved, the firm and secured creditor could not have been motivated by the desire to profit from an inefficient waiver that reallocates value from unsecured creditors. Thus, the waiver should be enforced."). 
contract, ${ }^{150}$ and even he would imply it from the existence of the contract on the public record for a specified period before bankruptcy. ${ }^{151}$

Relaxing the requirement for active, knowledgeable participation by all creditors in bankruptcy contracting reduces transaction costs. At the same time, however, it exposes the interests of nonparticipating creditors to the redistributional impulses of the active, knowledgeable participants. One cannot simply assume that if the redistributions thus achieved are small, the accompanying declines in efficiency will be small as well. William Whitford and I have shown that there is no necessary relationship between the two. ${ }^{152}$ The strength of the redistributional impulses evident in the current pattern of bankruptcy contracting, combined with the largely unexplored potential for even small redistributions to have large adverse effects on efficiency, should give pause to future bankruptcy-contracting theorists. Solutions that purport to take account of the preferences of all creditors without actually doing so may be both redistributional and inefficient.

150. See Rasmussen, supra note 1 , at 118 (stating that whenever the debtor seeks to change from a Chapter 7-only selection to a Chapter 11 selection, "change in the corporate charter should be allowed only with the consent of all of the creditors").

151. See supra note 8 .

152. See LoPucki \& Whitford, supra note 73 , at $782-85$ (providing an example showing large distributional effects from attempts by reorganization management to achieve small efficiency gains). A holdup that leads to a failure in contracting is an example of large efficiency effects from attempts to achieve small distributional gains. 